\title{
Impact of SHG on Income of Pig Farmers in Mizoram of North East India
}

\author{
Hmingthanzuala ${ }^{1}$, Samares Kumar Das ${ }^{1 *}$, Saidur Rahman ${ }^{1}$, T. C. Tolenkhomba ${ }^{2}$ and Prasanta Saikia ${ }^{3}$ \\ ${ }^{1}$ Dept. of Veterinary \& Animal Husbandry Extension, College of Veterinary Sciences \& Animal Husbandry, Central \\ Agricultural University, Selesih, Aizawl, Mizoram (796 014), India \\ ${ }^{2}$ Dept. of Animal Genetics and Breeding, College of Veterinary Sciences \& Animal Husbandry, Central Agricultural \\ University, Selesih, Aizawl, Mizoram (796 014), India \\ ${ }^{3}$ Dept. of Livestock Production Management, College of Veterinary Sciences \& Animal Husbandry, Central Agricultural \\ University, Selesih, Aizawl, Mizoram (796 014), India
}

\section{Article History}

Manuscript No. AR1562

Received in $15^{\text {th }}$ March, 2016

Received in revised form $16^{\text {th }}$ May, 2016

Accepted in final form $29^{\text {th }}$ May, 2016

\section{Correspondence to}

${ }^{*} E$-mail: samcau.d1@gmail.com

\section{Keywords}

Mizoram, SHG,pig farming, impact on income

\begin{abstract}
The success of Bangladesh Grameen Bank has made microfinance a means for providing credit to the poor through Self-help Groups (SHGs). Mizoram is one of the eight states in north-eastern India. Self Help Groups (SHGs) is being formed by government agencies such as National Bank for Agriculture and Rural Development (NABARD), District Rural Development Agency (DRDA), etc. Also several NGOs are forming SHGs such as World Vision, Open Doors, Goodwill, etc. Piggery plays a role in the economy of the state more than other livestock. Pig-rearing is an important SHG activity. But negligible studies have been conducted on the SHGs in Mizoram. Keeping this in view, present study was undertaken in Serchhip and Kolasib district where pig-rearing SHGs are formed by National Rural Livelihood Mission (NRLM). Twenty Self-help Groups (SHGs) engaged in pig-rearing activity was studied to measure the impact of SHG on income of its members. The study was conducted in purposively selected two districts having four rural development blocks. Five SHGs from each block and five SHG members from each of 20 SHGs were selected randomly. Total $100 \mathrm{SHG}$ members were interviewed. Paired $t$-test showed significant increase in income after joining the group. Study concludes that pig rearing can be undertaken by SHGs to improve the economy of the people. There is a need to study the sustainability of pig-rearing SHGs in the study area.
\end{abstract}

\section{Introduction}

The success of Bangladesh Grameen Bank (Yunus, 1998, 2004) has made microcredit or microfinance an important means for providing small credit to the rural poor through Self-help Groups (SHGs) to solve the problem of inadequate access of banking services by the poor (Rajasekhar, 2000). With more than 35 years of experience in the field, Bangladesh and India have often been referred to as the "Mecca of microfinance". Bangladesh today has more than 35 million active clients, while India has more than 27.5 million (Sa-Dhan, 2012: cited in Zulfiqar, 2014). 'Microcredit' is the practice in developing nations of providing small loans, typically less than US $\$ 500$, to self-employed people (Morduch, 2011). Although there is a history of microfinance in the informal sector of rural India, officially it was started when the National Bank for Agriculture and Rural Development (NABARD) launched
SHG-bank linkage program during 1992-93 with the launch of Swarnjayanti Gram Swarozgar Yojana (Harper et al., 2005; Jindal, 2005; Kalpana, 2006; Bera, 2008; Sarkar, 2008; Karmakar, 2009). Impressed by the remarkable success of women SHGs in Andhra Pradesh, the World Bank recommended that the model could be replicated in other states in India and in other countries (Ramesh, 2007; Reddy, 2008). In the context of developing programs for the poor, SHGs have emerged as effective tools for poverty alleviation as well as for social and economic empowerment of the rural poor particularly women (Kashid et al., 2009; Sajesh et al., 2011).

Mizoram is not lagging behind. In Mizoram too, the strength of Self Help Groups (SHGs) is ever growing with the initiative taken by government agencies such as National Bank for Agriculture and Rural Development (NABARD), District Rural Development Agency (DRDA), Mizoram State Rural Livelihood Mission/National Rural Livelihood Mission 
(MSRLM/NRLM), National Urban Livelihood Mission (NULM) and North East Rural Livelihood Project (NERLP). There are also several NGOs which are operational at present, in forming and monitoring SHGs in different areas of the state such as World Vision, Centre for Community Development (CCD) through network, education, research, training, resource mobilization and capacity building (CODnerc), Open Doors, Goodwill, etc. The State Level Banker's Committee Meeting for Mizoram, State Bank of India (2015) showed that there were 1,188 SHGs in the state which have direct linkage with micro-credit institute.Earlier SHGs were formed under Swarnjayanti Gram Swarojgar Yojana (SGSY) throughout Mizoram. Formation of SHGs under SGSY was ended in 2010. Now since 2011-12 SHGs are being formed under National Rural Livelihood Mission (NRLM) only in two districts of Mizoram-Serchhip and Kolasib.

Pig is one of the most important livestock species reared in the north-eastern states of India. The region has 38-lakh pigs which is about $28 \%$ of the country's pig population (DES, 2010). Mizoram, being topographically challenged for large scale food grain cultivation due to its steep slopes and hilly terrains and the practice of traditional subsistence "Jhum" cultivation of rice, it is customary for the Mizo to rear one or two pigs as a source of subsidiary income. According to 2012 livestock census, there were 2,45,238 pigs in Mizoram contributing $2.38 \%$ to the nation's pig population. The human population census of 2011 shows that the total occupied households in Mizoram was 2,57,581. It can be assumed that there was one pig for almost every household in the state. Therefore, piggery plays a crucial role in the economy of the state than other species of livestock.Consequently, pig rearing has become one of the important SHG activities of Mizo people. However, very negligible studies have been conducted on the SHGs in Mizoram. Keeping this in view, the present study was undertakento measure the impact of SHG on income of SHG membersin the district of Serchhip and Kolasib where the National Rural Livelihood Mission (NRLM) has been forming SHGs around piggery since 2012.

\section{Materials and Methods}

The study was conducted in two districts of Mizoram, namely, Serchhip and Kolasib. Serchhip, located at $23.3^{\circ} \mathrm{N} 92.83^{\circ} \mathrm{E}$, lies between the two very important rivers of Mat and Tuikum. According to census (2011), the district had a population of 64,875 of which male and female were 32,824 and 32,051 , respectively with a density of $46 \mathrm{~km}^{-2}$ with an area of about $1,421 \mathrm{~km}^{2}$. The district had two development blocks, namely, Serchhip and East Lungdar and had the highest literacy in India. Kolasib district is bound on the north and north-west by Hailakandi district (Assam), on the west by Mamit district, on the south-east by Aizawl district and on the north-east by Cachar district (Assam). According to census (2011), the district had a population of 83,054 of which male and female were 42,916 and 41,037 , respectively with a density of $61 \mathrm{~km}^{-2}$ and an area of $1,382.51 \mathrm{~km}^{2}$. The district had two development blocks, namely, Bilkhawthlir and Thingdawl and had 93.5\% literacy. Two districts (Serchhip and Kolasib) were selected purposively as these were the only two districts in Mizoram under which the National Rural Livelihood Mission (NRLM) have been taking initiative for formation and monitoring of SHGs. Each district had two blocks from which SHGs engaged in pig rearing activity for at least two years were shortlisted. Among the shortlisted SHGs from each block five were randomly selected. Thus, a total of 20 SHGs were selected and from each of the 20 SHGs five members were randomly selected on lottery basis to have a sample size of 100 SHG members for study. It was intended to study whether income of the SHG members was increased significantly after joining as a group member. For this purpose the following hypothesis was formulated:

$\mathrm{H}_{0}=$ There was no significant difference between the mean income of SHG members before and after joining SHG.

$\mathrm{H}_{\mathrm{a}}=$ There was significant difference between the mean income of SHG members before and after joining SHG.

The hypothesis was tested by paired $t$-test at $d f=(n-1)=(20-1)=19$ comparing Table value for two-tailed test at 5\% level of significance. The choice of two-tailed or one-tailed test depends on the objectives and consequently on the formulation of null hypothesis or alternative hypothesis. 'Null hypothesis' is a hypothesis of 'no difference' (Kerlinger, 2000). Two-tailed test is chosen for testing difference only. If a null hypothesis is proposed on the contention that there was no difference between the mean scores of paired-observations (mean income before and after joining SHG) the concern is only on the difference and not on the superiority or inferiority, increase or decrease, and the like. Two-tailed test is applied in such a situation. If the hypothesis is formulated on the contention to express the superiority or inferiority, increase or decrease, etc. between the mean scores of paired-observations by indicating a direction of difference, one-tailed test is applied (Ray and Mondal 2004). Since in the present investigation the null hypothesis was stated as:

$\mathrm{H}_{0}=$ There was no significant difference between the mean income of SHG members before and after joining SHG.

$\mathrm{H}_{\mathrm{a}}=$ There was significant difference between the mean income of SHG members before and after joining SHG.

So, application of two-tailed test was useful for the consultation of the Table value of $t$ in this statistical Table.

\section{Results and Discussion}

20 paired observations (mean income of $n=20$ groups before 
and after joining group) were taken which yielded the following result:

\begin{tabular}{|c|c|c|c|c|}
\hline $\begin{array}{l}\text { Sl. } \\
\text { No. of } \\
\text { group }\end{array}$ & $\begin{array}{c}\text { Mean } \\
\text { monthly } \\
\text { income } \\
\text { of SHG } \\
\text { before } \\
\text { joining }\left(\mathrm{x}_{1}\right)\end{array}$ & $\begin{array}{c}\text { Mean } \\
\text { monthly } \\
\text { income of } \\
\text { SHG after } \\
\text { joining }\left(\mathrm{x}_{2}\right)\end{array}$ & $\begin{array}{c}\mathrm{d} \\
\left(\mathrm{x}_{2}-\mathrm{x}_{1}\right)\end{array}$ & $d^{2}$ \\
\hline 1. & 87000 & 124000 & 37000 & 1369000000 \\
\hline 2. & 94000 & 120000 & 26000 & 676000000 \\
\hline 3. & 78000 & 102000 & 24000 & 576000000 \\
\hline 4. & 73000 & 94000 & 21000 & 441000000 \\
\hline 5. & 51000 & 76000 & 25000 & 625000000 \\
\hline 6. & 50000 & 74000 & 24000 & 576000000 \\
\hline 7. & 88000 & 112000 & 24000 & 576000000 \\
\hline 8. & 65000 & 92000 & 27000 & 729000000 \\
\hline 9. & 56000 & 80000 & 24000 & 576000000 \\
\hline 10. & 70000 & 96000 & 26000 & 676000000 \\
\hline 11. & 90000 & 116000 & 26000 & 676000000 \\
\hline 12. & 109000 & 114400 & 5400 & 29160000 \\
\hline 13. & 51000 & 78000 & 27000 & 729000000 \\
\hline 14. & 94000 & 118000 & 24000 & 576000000 \\
\hline 15. & 54000 & 80000 & 26000 & 676000000 \\
\hline 16. & 68000 & 92000 & 24000 & 576000000 \\
\hline 17. & 66000 & 94000 & 28000 & 784000000 \\
\hline 18. & 64000 & 86000 & 22000 & 484000000 \\
\hline 19. & 56000 & 78000 & 22000 & 484000000 \\
\hline \multirow[t]{2}{*}{20.} & 67000 & 86000 & 19000 & 361000000 \\
\hline & & & $\begin{array}{c}\Sigma \mathrm{d}= \\
481400\end{array}$ & $\begin{array}{c}\Sigma d^{2}= \\
12195160000\end{array}$ \\
\hline
\end{tabular}

Paired $t$-test states that:

$$
t=\frac{\bar{d}}{S(\bar{d})} \text { at }(\mathrm{n}-1) d f
$$

Where, $\mathrm{n}=$ Pairs of observation $=20$

$\bar{d}=$ Mean of the differences in each pair $=$

$\frac{\sum \mathrm{d}}{\mathrm{n}}=\frac{481400}{20}=24070$

$\mathrm{S}(\bar{d})=$ Standard error of $\bar{d}=\sqrt{\mathrm{s}^{2} / \mathrm{n}}$

$\mathrm{s}^{2}=\frac{1}{\mathrm{n}-1}\left[\sum \mathrm{d}^{2}-\frac{\left(\sum \mathrm{d}\right)^{2}}{\mathrm{n}}\right]$

$\mathrm{s}^{2}=\frac{1}{20-1}\left[12195160000-\frac{(481400)^{2}}{20}\right]$

$=\frac{1}{19}\left[12195160000-\frac{231745960000}{20}\right]$

$=\frac{1}{19}[12195160000-11587298000]$

$=\frac{1}{19}[607862000]$

$=31992736.8421$
$S(\bar{d})=\sqrt{\frac{31992736.8421}{20}}$

$=\sqrt{1599636.8421}$

$=1264.767$

$t=\frac{\bar{d}}{S(\bar{d})}$

$=\frac{24070}{1264.767}$

$=19.03$

The value of $t$ with $19 d f$ at 5 and $1 \%$ level of significance (two-tailed test) are 2.093 and 2.861, respectively. Since the calculated value of paired $t$-test is 19.03 which is much higher than the statistical Table value at $1 \%$ level of significance with $19 d f$ the null hypothesis can be rejected not only at $5 \%$ but even at $1 \%$ level of significance also.So, the alternative hypothesis: "There was significant difference between the mean incomes of SHG members before and after joining SHG, has been accepted. The mean annual income of the respondents before joining the group was ₹ 71,550 (₹ 5,963 monthly), whereas the mean annual income after joining the group was ₹ 95,620 (₹ 7,968 monthly). Thus, there was an average increase of ₹ 2,005 member ${ }^{-1}$ after joining SHG. Since the members were regular pig farmers there was no drastic change of income initially with the addition of one piglet. But within a span of 2-3 years the difference in the average income before joining and after joining was ₹ 2,005 monthly. This might be the result of rise in piglet price which was ₹ 5,000 and pork was ₹ $250 \mathrm{~kg}^{-1}$ at the time of data collection (2015). Many studies also proved that SHG helped weaker sections of the society particularly women in terms of increased income and employment, social participation and overall empowerment (Hegde, 1999; Dwarkanath, 2002; Hirevenkanagounda et al., 2005; Tripathy, 2006; Feroze et al., 2011; Bora and Talukdar, 2012; Sundaram, 2012; Kumar, 2013; Pahuja and Singh, 2013; Rewani and Tochhawng, 2014).

\section{Conclusion}

Self-help Groups (SHGs) engaged in pig-rearing activity in Mizoram was studied in two purposively selected districts. The objective was to measure the impact of SHG on income of its members. A random sample of 100 SHG members was interviewed. Paired t-test showed significant increase in income after joining the group. Study concludes that pig rearing can be undertaken by SHGs to improve the economy of the people. Study suggests that there is a need to study the sustainability of pig-rearing SHGs in the study area.

\section{References}

Bera, S., 2008. Program design and impact assessments: 'Success' of microfinance in perspective. Economic and 
Political Weekly, 9 August, 77-85.

Bora, P., Talukdar, R.K., 2012. Functioning and sustainability of women Self Help Groups of Assam: An analysis based on credit system and income generation. Indian Research Journal of Extension Education12(2), 107-112.

DES, 2010. Statistical handbook of Mizoram. Directorate of Economics and Statistics, Government of Mizoram, Aizawl.

Dwarkanath, H.D., 2002. Rural credit and women self-help groups: A profile of Ranga Reddy district of Andhra Pradesh. Kurushetra 51(1), 9-15.

Feroze, S.M., Chauhan, A.K., Chakravarty, A.K., 2011. Microfinance and income from dairy in Haryana: An impact analysis. Indian Journal of Animal Science 81(7), 751-756.

Harper, M., Berkhof, A., Ramakrishna, RV., 2005. SHG-bank linkage: A tool for reforms in cooperatives? Economic and Political Weekly, 23 April, 1720-1725.

Hegde, N., 1999. Empowerment of rural women through selfhelp groups. The BAIF Journal 19(2), 1-2.

Hirevenkanagounda, L.V., Kunnal, L.B., Hanchinal, S.N., Bheemappa, A., Maraddi, G.N., 2005. Impact of self-help groups on rural poor. Proceeding of National Seminar on Green to Evergreen: Challenges to Extension Education. 15-17 December, Indian Agricultural Research Institute, Pusa, New Delhi.

Jindal, A., 2005. Microfinance and SHGs: Role of government institutions. Economic and Political Weekly, 17 September, 4178-4179.

Kalpana, K., 2006. Microcredit wins Nobel: A stocktaking. Economic and Political Weekly, 16 December, 51105113.

Karmakar, K.G., 2009. Emerging trends in microfinance. Economic and Political Weekly, 28 March, 21-24.

Kashid, K., Wankhade, P.P., Mankar, D.M., 2009. Empowerment status of rural women through Self Help Groups. Indian Journal of Extension Education 45(3\&4), 106-112.

Kerlinger, F.N., 2000. Foundation of Behavioural Research. Surjeet Publications, Delhi.

Kumar, L., 2013. Illusion of women empowerment in microfinance: A case study. Economic and Political Weekly, 13 April, 70-76.

Morduch, J., 2011. Why finance matters? Science 332(6035),
1271-1272.

Pahuja, S., Singh, A.K., 2013. Self Help Groups: A means to empower rural women. Indian Journal of Extension Education 49(1\&2), 112-114.

Rajasekhar, D. (2000) Microfinance programs and women's empowerment: A study of two NGOs from Kerala. Journal of Socialand Economic Development 3(1), 76-94.

Ramesh, J., 2007. Self-help Groups revolution: What next? Economic and Political Weekly, 8 September, 3621-3624.

Ray, G.L., Mondal, Sagar., 2004. Research Methods in Social Sciences and Extension Education. Kalyani Publishers, Ludhiana.

Reddy A. 2008. Self-help groups in India: A catalyst for women economic empowerment and poverty eradication. Proceeding of $33^{\text {rd }}$ Global Conference of ICSW, 30 June-4 July, TOURS, France.

Rewani, S.K., Tochhawng, L., 2014. Social empowerment of women Self Help Group members engaged in livestock rearing. Indian Research Journal of Extension Education 14(2), 116-119.

Sajesh, V.K., Ramasundaram, P., Singh, P., 2011. Impact of Self Help Groups on the empowerment of rural women: A case of Kudumbasree Program in Kerala. Indian Journal of Extension Education 47(3\&4), 14-19.

Sarkar, D., 2008. Indian microfinance: Lessons from Bangladesh. Economic and Political Weekly, 5 January, $18-20$.

Sundaram, A., 2012. Impact of Self-help Group in socioeconomic development of India. Journal of Humanities and Social Science 5(1), 20-27.

Tripathy, K.K., 2006. Micro-credit intervention and poverty alleviation. Kurukshetra 54(11), 4-8.

Yunus, M., 1998. Alleviating poverty through technology. Science 282(5388), 409-410.

Yunus, M., 2004. Grameen Bank, microcreditand Millennium Development Goals. Economic and Political Weekly, 4 September, 4077-4080.

Zulfiqar, G., 2014. Microfinance: To what end? Findings from Pakistan. Economic and Political Weekly, 8 March, 63-67. 